\title{
Making Sense of the College Curriculum
}





\section{Making Sense of the College Curriculum}

Faculty Stories of

Change, Conflict,

AND ACCOMmodation

ROBERT ZEMSKY, GREgory R. Wegner, AND AnN J. Duffield 
Library of Congress Cataloging-in-Publication Data

Names: Zemsky, Robert, 1940- author. | Wegner, Gregory R., 1950- author. | Duffield, Ann J., 1947- author.

Title: Making sense of the college curriculum : faculty stories of change, conflict, and accommodation / Robert Zemsky, Gregory R. Wegner, and Ann J. Duffield.

Description: New Brunswick, New Jersey : Rutgers University Press, [2018] | Includes bibliographical references and index.

Identifiers: LCCN 2017053554 | ISBN 9780813595023 (cloth : alk. paper)

Subjects: LCSH: Education, Higher-Curricula-United States. | Education, Higher-

Aims and objectives-United States. | College teaching-United States.

Classification: LCC LB2361.5 .Z45 2018 | DDC 378.1/990973-dc23

LC record available at https://lccn.loc.gov/2017053554

A British Cataloging-in-Publication record for this book is available from the British Library.

Copyright (C) 2018 by Robert Zemsky, Gregory R. Wegner, and Ann J. Duffield All rights reserved

No part of this book may be reproduced or utilized in any form or by any means, electronic or mechanical, or by any information storage and retrieval system, without written permission from the publisher. Please contact Rutgers University Press, 106 Somerset Street, New Brunswick, NJ 08901. The only exception to this prohibition is "fair use" as defined by U.S. copyright law.

(6) The paper used in this publication meets the requirements of the American National Standard for Information SciencesPermanence of Paper for Printed Library Materials, ANSI Z39.48-1992.

www.rutgersuniversitypress.org

Manufactured in the United States of America 
Making Sense of the College Curriculum is dedicated to the $187 \mathrm{fac}-$ ulty members who shared their stories with us-without their candor and willingness to talk about their frustrations as well as their aspirations, there would have been no tale to tell. 
